\title{
FUNCTIONAL ANALYSIS OF REPUBLIC OF CROATIA FOR SHORT SEA SHIPPING DEVELOPMENT
}

\begin{abstract}
From the aspect of the Republic of Croatia, short-sea shipping has multiple significance. Primarily, the short-sea shipping between the Croatian and Italian coast, diverting of a part of cargo that is transported from the European Union into the countries of south-eastern Balkan via Croatia, reduction in harmful emissions in traffic and increase of traffic in the domestic ports. From the aspect of Europe short-sea shipping refers to the movement of goods and passengers by sea between the ports located in Europe or between these ports and the ports outside Europe that have a joint sea border with Europe. The aim of introducing shortsea shipping are: relief of the burden on the European road routes and shift of transport of cargo and passengers to the maritime transport, improvement of traffic connections and competitiveness of Croatia with the European Union, as well as the connection of the Danube and the Adriatic.
\end{abstract}

\section{KEY WORDS}

short-sea shipping, Republic of Croatia, maritime routes, traffic corridors

\section{INTRODUCTION}

A port system is commonly defined as part of the world transport system in which changes between basic carriers of the maritime and land transport occur. It is a complex, dynamic, open, stochastic and organizational system which contains all the technical and organisational elements needed for operations of the most favourable transhipment process and its management.

The construction of wholesome technological transport systems is the way to the development of successful economics under all social and environmental conditions. Although it represents complex organizational ideas and inclusion into a concept of a technological system of wider technological structures than transport itself, it primarily includes a change in management and the decision-making process and subsequently a structural change as well. Therefore, based on the assumption that each organizational item, structure or unit can function as a sub-system of a corresponding technological system, the introduction of information technology into the port system can be a solid starting hypothesis.

Technological systems are defined as interactive units of technological resources of natural, human and social characteristics. Technological processes at port systems are carried out according to the demands of the subjects involved in the port system itself. Basic technological processes are: cargo loading/unloading, control of entering and existing of port users, storing zone procedures and management of port facilities.

A special economic and geopolitical dimension of the Republic of Croatia lies in the fact that along its entire length it stretches along the eastern coast of the Adriatic. The activities within maritime economy encompass a wide range: sea shipping transport of people and cargo, shipbuilding, tourism, port activities, servicing maritime and transport activities, industrial use of energy and biological sources from the sea, sea and coast protection, entertainment, and education of seamen.

One may assess the actual situation of the Croatian maritime economy being a vital segment of the integral national economy as insufficiently developed. The last decade has been marked not only by stagnation but also by a decline in the intensity of all the economic activities related to the sea. Such falling tendency represents a loss for the national economy and means an alarming lagging behind the world events in maritime economy and traffic.

The role of maritime economy in the economic system of Croatia should represent the foundation of the development of the national economy and should be the guiding principle in defining the strategic goals of successful integration of Croatia into the European and world traffic and economic flows and corridors. 


\section{DEVELOPMENT OF SHORT- SEA SHIPPING IN CROATIA}

The world maritime economy has acquired the characteristics of a highly industrialized and technically and technologically advanced branch with the use of new technologies and information technology with the aim of achieving optimal logistic and economic effects. The evolution of the world maritime economy has been marked by globalization processes, liberalization and standardization, providing great opportunities to those who timely and efficiently adapt to the new conditions and codes of conduct on the competitive market.

If the Republic of Croatia wants to acquire equality on the competitive market, she can do it only with adequate development of competitive maritime activities determining the criteria of development, goals and measures that would reliably define the methods of catching up and adapting to new European and world tendencies.

The Republic of Croatia disposes of extraordinary natural and human resources. The maritime economy has stayed undeveloped due to the following reasons:

- inadequate technical and technological equipment (interoperability aspect);

- failure to follow the European and world tendencies in maritime economy;

- non-harmonized development of single segments of the maritime system.

In accordance with the Constitution of the Republic of Croatia, the sea, coast, islands as well as the regions of extreme economic and ecological significance are of special interest and have special national protection, and they form, according to the Maritime Code, the maritime property. With the aim of reviving and evaluating the sea and the coast, the Republic of Croatia needs to initiate and establish an integral model of integral management of the sea property ensuring maximal economic profit and protecting and preserving natural resources. The concession system on the maritime property has to be clear and transparent, by determining the method in which the maritime property should be evaluated and determining the concession fees, but with stronger economic and legal safety of the concessionaires.

The Croatian port system needs to be completely reorganized, modernized, redefined and restructured. The ports of Rijeka and Ploče may develop in the future as cargo ports, and in the maritime passenger traffic the ports of Rijeka, Zadar, Split and Dubrovnik should become the macrologistic centres.

The measures of port policy with the aim of wellthought profiling of the Croatian ports need to define, concretize and simplify:

- the financing methods and amount of investments into the port infrastructure;
- the construction of land traffic routes towards the hinterland;

- the method of defining the port area and granting of concessions;

- port management in the ports of special significance for the Republic of Croatia i.e. the county and local ports.

The geo-traffic position of Croatia is characterized by extremely long and indented coast. Such natural attribute inevitably stipulates adequate traffic connections:

- longitudinal connection of the coast,

- transversal land - island connections,

- transversal connections between the eastern and the western coast of the Adriatic Sea.

The longitudinal coastal connection of the Croatian coastal region can be done appropriately by land routes, i.e. sea routes, that is, by organizing the "Motorways of the Sea".

The "Motorways of the Sea" with numerous connections towards the islands would be a modern longitudinal and transversal traffic route that would mean the revival of the coast, islands and of all the economic activities related to the sea ranging from the ports, ship operators, to tourism and fishery. The organization of such a traffic route requires well-thought guidelines and significant initial financial investments into:

- definition of ship lines,

- modernization and expansion of the fleet by adequate vessels,

- profiling and equipping of ports, small ports and car-ferry landings.

Investments into the establishment and maintenance of such a form of transport would mean significant gains since the multiplicative factors on the entire national economy would be multiple.

Proper implementation of the set goals with consistent compliance with the proposed measures is impossible without qualified staff. A well-defined development of the lagging behind maritime system of a wealthy maritime country needs to be implemented by recognizing the national, economic, legal and political resources but in such a way as to start from the initial premise that the world sea is one and that the world maritime market is unique.

Maritime traffic should be accepted as an economic activity in the function of the development of national industry, since it uses diverse industrial products and insured overseas transport as part of the foreign trade.

Maritime traffic in the Republic of Croatia is characterized by long-term orientation of the ship operators to so-called "cross trade" which means maritime - transport services between foreign ports, as consequence of:

- specialization of ship operators for special types of cargo; 
Table 1 - Projection of the growth of maritime traffic from 2000 to 2010

\begin{tabular}{||l||c|c|c|c|c|c|c|c||}
\hline \multicolumn{1}{|c|}{ Description } & Growth rate & 2001 & 2003 & 2005 & 2007 & 2008 & 2009 & 2010 \\
\hline \hline $\begin{array}{l}\text { Cargo } \\
\text { (in 000 tonnes) }\end{array}$ & 4 & 15,442 & 16,702 & 18,065 & 19,540 & 20,321 & 21,134 & 21,980 \\
\cline { 2 - 10 }$y$ \\
\hline $\begin{array}{l}\text { Passengers } \\
\text { (in 000 passengers) }\end{array}$ & 7 & 16,345 & 18,713 & 21,425 & 24,530 & 26,247 & 28,084 & 30,050 \\
\cline { 2 - 11 } \\
\hline
\end{tabular}

Source: Ministry of the Sea, Transport and Communications of the Republic of Croatia, Zagreb, 2000

- insufficiently comprehensive national overseas foreign trade exchanges;

- insufficient interest of national foreign trade organizations for the cooperation with national, first of all line ship operators.

Apart from cargo maritime traffic it is necessary to mention also the passenger traffic, i.e. concrete maritime lines intended for the carriage of passengers and/or vehicles, and they are determined on the basis of the planned annual and seasonal demands, i.e. demographic and economic policies of the country and single coastal localities.

Maritime traffic is part of the integral system which according to the economic development is classified as one of the propulsive sectors of the Croatian economy and should in the period from 2000 to 2010 realize an average annual growth rate in the amount of four and seven percent.

Considering the significance of the maritime traffic special attention in the mentioned period needs to be directed to giving incentive to the development of sea shipping and sea ports. Since there are interdependence and interaction connections between the development of the maritime and land traffic, the development of one branch can positively reflect on the other and vice versa.

To realize the mentioned projections of the development of the Croatian seaports it is necessary to form administrative, organizational, information and economic preconditions which would enable strengthening and expansion of the gravitation port areas, and create conditions for the introduction and development of advanced transport technologies.

\section{TECHNICAL ANALYSIS OF THE CROATIAN PORT SYSTEM AND MARITIME NAVIGATION FOR THE PURPOSES OF SSS DEVELOPMENT}

Long and well-indented coast along with 4058 $\mathrm{km}$ islands' coastal line is the reason for existence of many marinas and ports, out of which seven international ports are the most significant ones: Pula, Rijeka, Zadar, Šibenik, Split, Ploče and Dubrovnik. Total cargo volumes of these ports amount to 39 million tonnes, out of which 23 million tonnes are bulk cargo and 16 million tonnes liquid cargo at the port of Rijeka oil terminal. Most of the cargo volumes refer to ports of Rijeka and Ploče. Almost the same indicators are representative of the passenger transport, which has decreased by 20 per cent. The basic problem is the old age of most of the infrastructural facilities which as such use only 30 to 50 per cent of their capacity.

When elaborating on applied transport technology, there are cellular, container, Ro-Ro vessels and general cargo vessels. Various cargo handling techniques are possible: cargo can be lifted and lowered in the LoLo (Lift on - Lift off) manner, pulling in the cargo on the Ro-Ro (Roll on - Roll off) level, combined lifting, lowering and pulling in Fo-Fo (Float on - Float off). Also, all three cargo handling techniques are being used today at the same time. The organization of maritime port procedures is marked by a complex port system functioning within the terms of technical-technological changes in the maritime transport.

Technical elements of the port system are as follows: infrastructure, suprastructure and transhipment machinery. Port infrastructure is comprised of all facilities at the territory of a port or a terminal which are at the same time utilized by all working organizations, port bodies and institutions related to the area.

The suprastructure consists of: electrical and water installations, alarming and fire fighting related devices, communication and telecommunication equipment and lightning arrester.

The transhipment facilities of a port or a terminal are transport facilities and facilities for cargo loading, unloading and transhipment on and off vessels. Coordination in port transport is conditioned by organized, joint activities of port organizations (port operators, concessionaires). The basic reason for port coordination and organization is defined by its legal, economic, operative and technical elements.

Successful functioning of a port system is not defined only by infrastructure, suprastructure and transhipment facilities available, but also by detailed identification of interest groups and their interactions according to national legislation.

When analyzing the basis and characteristics of port systems, it is imperative to define the area on which the system functioning is organized. Spatial layout of the port system must be a result of scientific research and systematic planning. Planning, construc- 
tion, work and development of the port production system are dependant on the results which are obtained at the sight and the processes which are used to retrieve those results. All specific elements and development possibilities must be synchronized with the national economic interests and the general development of the port system.

Maritime ports, a case of lex specialis, are regulated according to the Act on Maritime Property and Maritime Ports. All ports open for public transport are divided into three categories according to the size and significance for the Republic of Croatia. Among these ports, ports of Rijeka and Ploče have been identified as the most important commercial ports in Croatia according to their transport volumes and their significance in the Croatian and European traffic network. On the basis of their annual transport volumes, the remaining ports have been categorized as secondary ports.

In the period between 2006 and 2013, the investment plan in the above stated ports totals to 531 million euro. The investments will be distributed in the following manner:

- Port of Rijeka

- Port of Zadar

- Port of Ploče

- Port of Dubrovnik

- Port of Split

- Port of Šibenik

- 170 million euro

- 140 million euro

- 114 million euro

- 55 million euro

- 40 million euro

- 12 million euro

\section{LEGAL REGULATIONS AND RECOGNITION OF DEVELOPMENT OF SHORT SEA SHIPPING IN CROATIA}

Legal regulations and the recognition of the shortsea shipping development depends to a great extent on the harmonization of the standards of the European organization of the sea ports and the Society for short-sea shipping promotion, founded in Rijeka on 12 July 2005.

The European Union short-sea shipping has been defined by the Council Resolution brought on 11 March 1996 and expanded on 14 February 2000 related to the promotion of short-sea shipping and intermodal transport, and Regulation (EC) No. 1382/2003 brought by the European Parliament and Council, on 22 June 2003.

The purpose of the brought provisions refers to the promotion, incentive and facilitation of the development of short-sea shipping as the economically more cost-efficient and ecologically more acceptable alternative to land transport and intermodal transport of goods that will allow efficient and favourable usage of the user-oriented transport system, free of influence on the competition between the economic subjects.
The scopes of application are regional and local government, ports, port authorities, and sea economy.

According to the General administration for energy and transport of the European Commission in 2005, the Ministry appointed a contact person for short-sea shipping and joined the work of short-sea shipping task group which is responsible in the European Commission for the implementation of the planned legal and administrative measures to overcome delays in the transport thus achieving the throughput capacity and quality of the transport services. The same year (12 July 2005) saw the establishment of the Centre for short-sea shipping promotion by the Ministry of the Sea, Tourism, Transport and Development, forwarders, port authorities, Croatian railways, Society of road hauliers, ship operating agents and others.

An important segment for the recognition of the short-sea shipping development in the Republic of Croatia is the integration of the Republic of Croatia into the "Marco Polo" Program.

Positive consequences of implementing the Program are reflected in:

- diverting goods flows to the Croatian traffic routes;

- possibility of realizing the co-financing of the estab-

lishment of a service from the "Marco Polo" Program.

"The pre-accession maritime strategy has defined the objectives and measures for their realization, in order to fully harmonize the Croatian maritime legislation with the European Union acquis communautaire until the Croatian integration into the EU, and to adapt the maritime economy to the operation on the common market", this was said, among other things, at the presentation of the Pre-accession maritime strategy of the Republic of Croatia, with special consideration of the Adriatic protection.

\section{GUIDELINES FOR TRAINING AND EDUCTION OF HUMAN RESOURCES IN THE FIELD OF SSS PLANNING AND DEVELOPMENT}

By the year 2020, short sea shipping and related service providers will have gained access towards a larger, more professional and more motivated workforce. Individuals involved in SSS development aim at becoming SSS managers/organizers who will shape efficient logistic chains based on unbiased and neutral information and documentation. It takes "creative intelligence" and abilities to make strategic agreements with partners within the logistic chain, make valid demand projections, make balanced decisions on investments in SSS infrastructure and in the end, be skilled at utilizing restricted resources in order to make profit. Some European universities, business schools and institutes offer intermodal modules based on synchro- 
nized European programmes. Students can be connected on international level by electronic learning platforms, can use intermodal simulation scenarios and tools in order to train their decision-making when new logistic solutions are concerned.

SSS development will generate a large demand for qualified SSS workforce which cannot be met easily. Changes in transport systems will create a demand for new innovative strategies and concepts. Management and managers will require formation of an SSS network, channelling a large number of containers entering and exiting Europe towards reorganized and efficient maritime ports. This scenario will create a high demand for qualified SSS workforce which cannot be met easily. There will be a need for alternative features of the transport industry, which will enable human resources to deal with increased transport. At the same time, new, efficient strategies for improvement have to be elaborated, including new logistic IT concepts at terminals. It is necessary to attract young people and create back-up workforce in order to fully meet the potentials of new solutions and shape an image of an "intelligent" SSS sector.

\subsection{Attracting people to the SSS sector}

The transport sector has to compete with more attractive sectors (telecommunications, energy production, etc.) and to that purpose it has to attract people in order to meet the needs for intermodal workforce. Therefore, the image of the transport profession has to be improved by attracting more qualified personnel. One of the possibilities which were exploited in Europe as well is how to publicize the transport sector by means of traditional educational channels and alternatively through media channels as well. Another possibility which can be exploited is the development of integrated education and educational measures, for instance, connecting the educational sector with the transport sector professionals.

Due to changes in logistic systems in Europe, a need for new innovative strategies and concepts will arise, the concepts which will enable formation of a new type of "reverse" global logistic chains. Additionally, in the Asian-European context, Europe seeks alternative skills for the transport industry which will help the personnel to deal with increased traffic, i.e. coordinating the European intermodal counsel for education and training.

Within this Council, training of operative staff for transport modules (e.g. train operator or truck driver) is elaborated in principle only as it is covered by separate councils for railway, road, air and maritime transport. Education and training of "SSS coordinators/managers" refers to education of individuals responsible for combining typical advantages of different transport modes with the transport chain which is cost effective and saves time.

\subsection{Development of new learning and training methods within the field of SSS}

Several studies have indicated that there is a need for new training methods within the field of SSS (EU project ISIC: only $5 \%$ of universities provide models appropriate for SSS training).

New learning and training methods are the following:

- SSS manuals ("A-Z") as reference point for the SSS industry, which would be based on the existing manuals and results of national and EU projects, as well as best practice cases (e.g. cost-benefit analyses of the use of the existing results of research and development joined with production);

- Digital and interactive manuals;

- Electronic learning platforms, simulations, business cases;

- Business tools for decision making (support for SSS manager: planning and simulation of SSS before its realization; calculations; delivery deadlines; total costs; environment protection costs; budgeting; savings as a result of long-term investments (in safety and ecological aspects). Decision-making tools which are used in operative companies which have to be available for educational purposes. A future SSS creator needs to know the tools that will be used on daily basis;

- Planning platforms which are used for network simulation and work environment which encourages cooperation ;

- SSS centres for development and training.

Research needs to be focused on methods and tools which would integrate education and training into the SSS planning processes.

When new learning methods are concerned, conclusions are as follows:

- many transport experts have not graduated from institutes of higher education specialized in transport and traffic sciences;

- the existing basic business programmes do not provide enough logistics and SSS training;

- considering the nature of intermodal industry, trainers need to be familiar with real life scenarios;

- education needs to include research and development of the "SSS vision";

- SSS education and training require involvement of both public and private sectors;

- extended education and life-long-learning are crucial;

- experts need to be able to manage both technology and innovation. 
Table 2 - Basic competence of an SSS expert

\begin{tabular}{||l|l|l||}
\hline $\begin{array}{l}\text { UNDERSTANDING PRIN- } \\
\text { CIPLES OF ETHICS }\end{array}$ & ECOLOGICAL ANALYSIS & COMMMUNICATION SKILLS \\
\hline INTEGRAL ANALYSIS SKILLS & COMPUTER SKILLS & KNOWLEDGE ON TRANSPORT MODES \\
\hline MANAGEMENT SKILLS & $\begin{array}{l}\text { UNDERSTANDING OF TECH- } \\
\text { NOLOGY BACKGROUND }\end{array}$ & PLANNING SKILLS \\
\hline
\end{tabular}

On the basis of this research, the following points are considered to be of utmost importance:

- It has to be taken into consideration that in the future people are going to work with systems different from the ones that are used today. They are expected to be more complex and require different managerial skills;

- New approaches, such as e-learning, demonstrate a great potential;

- Managerial skills need to be broadened outside the traditional management in order to include ethics, customer care and strategic partnerships;

- Transport management, organizational structures and institutional organization need to be reorganized;

- There are two basic categories - expert staff and operational staff - each projecting different needs for skills. There is also the need for visionaries people who have the "wider picture" and understand the nature of change which affects transport. The following SSS aspects need to be emphasized:

- the need to understand technology and technological development,

- importance of organizational restructuring,

- impact of globalization on transport.

By combining the results, there are groups of nine points representing basic competences an SSS expert must demonstrate.

There are several general observations resulting from the analysis. By integrating the demand for SSS skills of workforce and providing basic educational programmes, the following conclusions can be made:

- skills expected from individuals at lower decisionmaking levels in SSS are more connected to skills needed for specific operational tasks;

- specialized skills can be acquired at different training programs, job experiences and training alongside work.

\section{MODEL OF SUSTAINABLE MOBILITY OF CARGO UNITS IN SHORT-SEA SHIPPING}

The European Commission adopted the orientation of the transport policy for the future. Mobility is of crucial significance for the European development and for the free movement of people. Negative influence of the mobility has to be reduced when energy or environmental quality are considered. Apart from actions that were defined by the White Paper in 2001, the required additional instruments include the logistic transport action plan and intelligent transport systems in order to make the mobility, which is competitive, reliable, safe, and environmentally friendly, "greener" and more efficient.

The European transport policy on sustainable mobility requires more political tools that would optimize the action of all transport modes and their combined use. The "Motorways of the Sea" and short-sea shipping have to develop with strong emphasis on the connections towards the interior. Mobility is one of four main objectives of the European transport policy that is required by all types of transport.

Simulation of sustainable mobility of cargo units in short-sea shipping is used for the purpose of improving the transport of cargo, functioning of the ports, faster throughput of cargo, adequate warehousing, delivering cargo from the port, and also for the purpose of preventing inadequate actions. It is used to forecast the system behaviour comparing it with the behaviour of the actual, i.e. the existing system.

According to Shannon, simulation is a process of designing a model of the actual system and experimenting with the new model in order to understand the behaviour of the system and/or estimate of different strategies for the system operation. Thus, for the model it is important that it is designed so that it imitates the behaviour of the reaction of the actual system towards the events that occur over time.

Simulation includes the construction of the model and its experimental use with the purpose of solving the set problem. The implementation of the methodology of simulation modelling is stipulated by the description of the system behaviour and development of a model that forecasts the future behaviour, i.e. effect that will result from the changes in the system or in its method of operation.

The basic concept of simulation is more understandable to the users than the analytic models and it is also more credible since it makes the comparison with the actual system and requires fewer assumptions on the characteristics of the system that is to be analyzed. It 
also allows insight into the work of the modelled system encompassing the most important variables for its functioning, allows control of the system management time providing a quick insight into the future needs. It is used to study the possibilities of introducing new technological and operative procedures, decision-making strategies of organizational structures and information throughput and fast cancellation of the current activities, as its most important advantage.

The models used in modelling may be material and symbolic, that is, mathematical, conceptual and computational.

The conceptual models are created on the basis of the perception of the structure and logic of the system operation or the problem that is modelled and are presented in the form whose significance has been precisely defined, which can be a diagram using precisely defined symbols. Such presentation provides visualization and model complexity, and communication among co-operators.

To form the model of sustainable mobility of cargo units, the methodology of the construction of the seaport architecture from the aspect of sea trade route will be used.

The procedures are as follows:

1. Identification of the problem with the aim of finding the answers to the following questions:

1. Who are the interested customers and service providers?

2. To which extent does the demand - supply relation of the port service vary over time?

3. Are there any restrictions regarding time and space?

2. Identification of the entities that participate in sustainable mobility of cargo units.

In identifying and estimating the importance of the entities it is necessary to find the answers to the following questions:

1. Which participants take part in short-sea shipping?

2. With what physical means do they participate in the transport process?

3. How do single means influence the functioning of the whole?

3. Identification of cause-effect relationship of the elements vertically. Here, the following questions need answers:

1. What are the primary activities of a short-sea shipping port?

2. Which are the existing traffic infrastructure facilities for the establishment of short-sea shipping?

3. Is there a possibility to change the transport system and establish a system that will support the upgrade, if we assume that there will be changes in the construction of the architecture of a short-sea shipping port?
Efficient transport systems are necessary for the prosperity of Europe; not only do they allow mobility of cargo and people, but they also have a significant influence on the economic growth, social development and environment.

Along with the European Union enlargement, there is a new imperative, sustainable development, which offers the possibility of adapting the common transport policy. This goal, as introduced in the Amsterdam Agreement, has to be achieved by integration of ecological thinking into the policy of the Community.

\section{LOGISTIC INTEGRATION OF SHORT- SEA SHIPPING THROUGH DEFINING OF MOTORWAYS OF THE SEA}

Logistics marks the physical distribution of products, developed as consequence of commercial activities. The basic task of logistics is to provide goods flows overcoming space and time as successfully as possible. By joining the process of coordination, planning, purchase, production, ordering and sales, logistics enables the realization of partial functions of numerous subsystems, such as transport, service quality control, information system, etc. The action of these partial functions as a unique system is based on logistic principles.

Logistic principles have initiated the advent of new "door-to-door" transportation systems, i.e. systems that ensure direct transport from the sender to the receiver of the goods. In this way the "integral transport chain" is established, which represents a continuous chain with the share of a greater number of logistic links from the goods sender to the receiver.

In the transport chain the goods are released for transport to that carrier of the transport chain who ensures the most rational transport with a certain quality of the transport service, including the type, travel path, time of the transport process and acceptable transport prices.

The concept of unique distribution understands interdependence and unity between different functional elements and information flows.

According to J.R. Robeson and W.C. Copacin the definition of logistics, considered from the customer's aspect, understands the philosophy used by the customer in accepting the service and thus integrates the evaluation of all the elements crucial for meeting the requirements with in-advance defined desired relation of the quality of service (benefit) and the cost.

The application of this definition of logistics in short-sea shipping, through the definition of the subsystem, the "Motorways of the Sea", as a logistic system, requires consideration of all the subjects of short-sea shipping, and not only of the "Motorway of 
the Sea" users, and determining of their requirements that define the functioning of the entire system.

The concept of traffic logistics today has been widely accepted and represents the optimization procedure of all the processes to ensure the changes in the cargo coordinates from the origin to the destination. With the aim of optimising the entire system, the logistics approach understands decision-making when, how and where the activities need to be undertaken.

The key elements of the logistic strategy development include:

1. knowing the point of costs in the logistics system;

2. promotion of the participants' connections;

3. development of a flexible transport system;

4. development of support through the logistics information integrated system with the management production process.

The logistic approach to defining of the "Motorways of the Sea" understands the integration of the short-sea shipping activities that directly or indirectly affect the final transport service, which apart from cargo handling, transport and resource management includes also a series of accompanying activities and their carriers whose harmonized action yields the desired results. Apart from the technological processes and their characteristics, the subjects are also being considered. In defining the "Motorways of the Sea" using the terminology of the logistic systems, the notion of "system subject" encompasses all the subjects.

The efficient realization of logistic activities and their space and time harmonization improves the quality of the users' services. The subjects, carriers of activities and actions in the system, try to implement the highly-developed technologies in order to reach the desired quality of service that is measured by the consumed time, personnel, equipment and overall costs. The continuous, time and space-harmonized flow of cargo from origin to destination in which all the activities take place is called the logistics chain, and the "Motorways of the Sea" has its place within this.

The notion of logistics chain is introduced with the aim of defining the position of the "Motorways of the Sea" integrated in short-sea shipping. The study of the logistics chain understands the study of all the subsystems of the logistics subsystem with the aim of reducing the overall logistics costs. Thus, it understands the research of the "Motorways of the Sea" as a subsystem, and the influence of costs resulting from the functioning of the "Motorways of the Sea" subsystem in the logistics system of short-sea shipping.

The basic requirements that have to be met by the "Motorways of the Sea" system as part of the logistics chain include:

- raising of the service quality,

- high level of flexibility and service adaptability,

- closed integration with other traffic subsystems,

- improved management strategy.

\section{MODERNIZATION PLAN OF THE MAIN MARITIME PORTS IN THE REPUBLIC OF CROATIA (PORTS OF INTERNATIONAL INTEREST AND COUNTY PORTS) AND THEIR INTEGRATION INTO THE SSS SYSTEM}

Valorisation of each transport route is determined by market demand, supply and general conditions. Supply is defined by transport capacities and services of all subjects involved in transport services, demand by the size and value of the area in which the demand for transport has occurred as well as the scope and structure of the demands in question. General conditions of the market are in fact potential competitors on the market, as well as other transport features that may occur.

The connection of transport and the economy is determined by fluctuations of basic indicators such as the gross domestic product, employment, investments or individual consumption on the one hand, and cargo and passenger volumes, size of the transport network, quantity and nature of transport systems on the other. The usual quantitative method of determining the connection indicates to which extent the cargo or passenger volume rate changes depending on the GDP or national income, for instance.

The transport sector in Croatia accounts for about 9\% of the total GDP which is slightly more than the same share in western European countries (e.g. Germany $-5.2 \%$, Denmark - $7 \%$ ). The reason for this is that the Croatian national area is U-shaped, which requires a higher density of transport infrastructure in relation to other south-eastern European countries covering a similar total area. Another possible reason is the need for rationalization within the transport trade.

The number of people employed in the transport, storage and connections branch in Croatia in 2005 was 79,187 , which is $7.2 \%$ of the total employed population. This is a slightly higher percentage than the European average, which is about $6 \%$.

In other words, the cooperation of the north Adriatic ports is not merely justified, but also necessary in order to provide their presence in the central European transit market, with relation to the growing competitiveness of north European ports and the accompanying land route which connects them with the central European hinterland.

Should the trends stated above continue, and their negative effects are not eliminated over a reasonable period of time, it can easily be assumed that the competitive character of the north Adriatic ports will be significantly smaller than their potentials. Therefore, relevant measures (related to railway, road, port infrastructure, liner services) have to be defined and adopted by the countries involved (Croatia, Italy and 
Slovenia) and the European Union, in order to amend the misbalance in question, within a reasonable midterm period.

The increasing port transport can be the basis for a new investment cycle to start, within which ports would modernize the existing port capacities and construct new, contemporary terminals. In relation to that, it should be noted that both ports are constructing terminals for container transhipment, which will have a significant effect on attracting container transport into Corridors $V_{B}$ and $V_{C}$, and therefore, on cargo flows of Corridor $\mathrm{X}\left(\mathrm{X}_{\mathrm{A}}\right)$ as they intersect.

Therefore, Corridor $V_{C}$ which represents a connection between northern - central and southern Europe has a significant importance within the process of economic and transport integration of the central-European area. Thus, it should be a competitive alternative by appropriate transport infrastructure, whether it is the Port of Ploče as a starting point of the corridor or road and rail connections of the $\mathrm{V}_{\mathrm{C}}$ Corridor.

The transport infrastructure which is old and outdated is the reason why transport is being shifted to closer neighbouring or to even further ports. For the purpose of attracting cargo volumes and meeting client needs for high quality transport services, modern road and railway infrastructure and suprastructure need to be built. New roads are planned in order to connect most adequately the Port of Ploče with its gravitational area. The role of the Government is crucial in these scenarios as it defines by means of transport policy measures which infrastructure is going to be built, and in this way, creates strong transport routes and corridors. Transport Corridor $V_{c}$ should have appropriate modern transport infrastructure which would facilitate expansion of the Port of Ploče and the entire transport route. Other than its impact on the Port of Ploče, the construction of new roads would enable expansion of the port and of the entire transport route. Additionally, the construction of new roads would enable social, cultural and civilizational interaction between different states and regions, and would create preconditions of future euro-regional cooperation at a large extent.

As an intermodal corridor, the base of the Corridor $\mathrm{X}$ and its branch $\mathrm{X}_{\mathrm{A}}$ are particularly interesting considering transit cargo flows which, at the south-easterncentral-western Europe route, transit the Croatian territory and by doing so, generate significant revenues for the local economy.

Considering the volumes of cargo flows, Corridor $\mathrm{X}$ has been considered an important Croatian Corridor, as well as a "political" one because the wartime operations on the territories of ex-Yugoslavia resulted in a decrease of cargo flows and their shift to other corridors.

However, cargo volumes are difficult to measure at Corridor X. Cargo flow volumes cannot be estimat- ed by measuring cargo flow volumes at one transit point (as it is the case with Corridor $V_{B}$ - the Port of Rijeka). The only method which can be used for the analysis and projections of cargo flows at Corridor $\mathrm{X}$ is the analysis and projection of international trade exchange between the countries of western, central and south-eastern Europe, which are on the Corridor.

Starting from the current state and the expected economy growth of the Republic of Croatia and the neighbouring countries, this research identifies the demand for:

- resolving administrative difficulties;

- coordination of organizational issues;

- improvement of transport infrastructure;

- staff education.

The development of the idea of Short Sea Shipping, i.e. liner service is closely related to and practically inseparable from intermodal transport. From the Croatian point of view, possible transport routes which would demonstrate beneficial effects of modal shift are:

- the route which connects the south of France, i.e. northern Italy with the central and central-eastern Europe;

- the route which connects central-eastern countries with northern Europe.

Measures and action plan of SSS development in the Republic of Croatia include:

1) Legislation-related measures:

- setting up and adopting administrative operations which are to be undertaken when a ship is arriving/leaving, in accordance with the 1965 resolutions of the FAL convention and the recommendations of the International Maritime Organization;

- setting up "Marco Polo" programmes in order to provide financial support of new liner services which have the effects that address the goals of the White Paper;

- introducing a new intermodal transport unit which could be transported in standardized containers (similar to standardized ISO containers), and which size would be adapted to other standardized forms of packing (palette) in order to cut costs and minimize delays in intermodal transport;

- setting up "motorways of the sea" which would provide transport between distant locations of the European Union at a lower expense and shorter time. This would eliminate the need for expensive road construction such as the one through the Alps or the Pyrenees;

- improvement of ecological aspect of Short Sea Shipping, primarily by reducing gas emission levels to adapt them to the VI MARPOL 73/78 Convention. 
2) Technical measures:

- coordination of the customs procedures within Short Sea Shipping in order to cut the time and costs of border delays;

- detecting and eliminating difficulties (bottlenecks) which diminish the overall efficiency of Short Sea Shipping and increasing efficiency of existing systems;

- unification of national border systems and the accompanying computer equipment with the final goal of substituting paper with electronic forms;

- support of SSS related research and technological development within the $7^{\text {th }}$ framework programme.

3) Working measures:

- simplification of administrative demands, particularly with departure/arrival procedures, i.e. procedures which connect different transport modes;

- support representatives of national authorities and facilitate their cooperation meetings for the purpose of know-how exchange;

- support the SSS development centres as independent bodies whose members are stakeholders within the transport sector;

- introduction of Short Sea Shipping to the public and change the general perception of SSS as a slow and inefficient transport concept;

- improvement of data collection methods which would provide a better picture of the current state of transport flows.

\section{CONCLUSION}

The geo-traffic position of Croatia is marked by extremely long and indented coast. Such a natural attribute inevitably requires adequate traffic connections:

- longitudinal connecting of the coast,

- transversal land-island connections,

- transversal connections between the eastern and western coast of the Adriatic Sea.

The very geographic shape of Croatia imposes the need for a complete traffic evaluation of its both arms, the Pannonian and the Adriatic, and their connection. Therefore, Croatia has high potential for short-sea shipping connection with EU.

Longitudinal connection of the Croatian coastal region can be adequately realized by land routes, i.e. by sea, that is, by organizing the "Motorways of the Sea".

The "Motorways of the Sea" with numerous connections towards the islands would be a modern longitudinal and transversal traffic route that would mean revival of the coast, islands and all the economic activities related to the sea from the ports, shipping operators to tourism and fishery. The organization of such a traffic route requires well-designed guidelines and significant initial financial investments into the definition of shipping lines, modernization and expansion of the fleet by adequate vessels and profiling and equipping of the ports, small ports, and car-ferry landings.

The European maritime corridors, the so-called "Motorways of the Sea", represent a new concept in the European traffic system. The short-sea shipping in the European maritime corridors should improve the European traffic system by releasing it from the domination of road transport. The European traffic corridors represent the main possibility for the European Union for the following several years of planning periods. However, the possible problems are of financial nature, both of the public and of the private sector. Apart from that, the following should be done, and that is that the existing infrastructure should be adapted in the ports and their hinterlands, the logistics activities should be stabilized with the application of new technologies, the investment funds should be available under the "Marco Polo" project, investments from the private sector or/and by the European Investment Bank or by the European Union members as independent investment sources.

To realize the mentioned projections of the development of the Croatian seaports it is necessary to create administrative, organizational, information and economic preconditions that would allow strengthening and expanding of the port catchment areas, and create conditions to introduce and develop modern transport technologies.

If Croatia wants to become equal on the competitive market, this can be done by adequate development of competitive maritime activities with determining the criteria of development, objectives and measures that would reliably define the methods of catching up and adapting to the new European and world tendencies.

\section{SAŽETAK}

\section{FUNKCIONALNA ANALIZA RH ZA RAZVOJ MEĐUOBALNE PLOVIDBE}

Međuobalno prometno povezivanje, s aspekta Republike Hrvatske, ima višestruko značenje. Prvenstveno međuobalno prometno povezivanje hrvatske $i$ talijanske obale, preusmjeravanje dijela tereta koji se iz Europske unije prevozi u zemlje jugoistočnog Balkana, preko Hrvatske, smanjenje emisije štetnih plinova u prometu i povećanje prometa u domaćim lukama. Međuobalna plovidba, s aspekta europskog prostora, odnosi se na kretanje roba i putnika pomorskim putem između luka smještenih u Europi ili između tih luka i luka izvan Europe koje morem graniče s Europom. Ciljevi uvođenja međuobalne plovidbe su: rasterećenje europskih cestovnih pravaca i preusmjeravanje prijevoza tereta i putnika na pomorski prijevoz, poboljšanje prometne povezanosti i konkurentnosti Hrvatske s Europskom unijom te povezivanje Dunava i Jadrana. 


\section{KLJUČNE RIJEČI}

međuobalna plovidba, Republika Hrvatska, pomorski pravci, prometni koridori

\section{LITERATURE}

[1] ADRIATIC3S project, Faculty of Transport and Traffic Sciences, PHARE, EU fund, 2009.

[2] Strategija razvoja pomorstva, Hrvatska u 21. stoljeću (Maritime Development Strategy, Croatia in $21^{\text {st }}$ century), Rijeka, 2000-2001

[3] Pomorski zakonik (Maritime Code), Official Gazette, Zagreb, No. 118/2004

[4] Poletan Jugović, T.: Integriranost $\mathrm{RH}$ u paneuropsku mrežu prometnih koridora (Integration of RH in PanEuropean Traffic Corridors Network), Maritime economy, Vol. 20, No.1, The Maritime University in Rijeka), Rijeka, 2006

[5] Hrvatsko pomorsko zakonodavstvo u procesu usklađenja s pravnom stečevinom Europske unije (Croatian Maritime legislation in harmonization process with European Union acquis communautaire), Ministry of the Sea, Tourism, Transport and Development, Zagreb, Croatia, 31 May 2006

[6] Predpristupna pomorska strategija Republike Hrvatske, s posebnim osvrtom na zaštitu Jadrana (Pre- accession Maritime Strategy of the Republic of Croatia, with special focus on the protection of the Adriatic), Ministry of the Sea, Tourism, Transport and Development, Dubrovnik, 22 May 2005

[7] Shannon, R. E.: Introduction to the Art and Science of Simulation, Proceedings of the 1998 Winter Simulation Conference, ed. D.J. Medeiros et al., 1998

[8] European Commission, White Paper, European Transport Policy for 2010, Time to decide, Brussels, 2001

[9] Perišić, B.: Integrated Logistic and Distribution System as Modern Technologies of Integration into European Transport System. The economic Journal, Oxford, 2, 1990

[10] Robeson, J.R., Copacino, W.C.: The Logistic Handbook, Anderson Consulting, 1994

[11] Jolić, N.: Funkcionalni i simulacijski model inteligentnih transportnih sustava u lukama (Functional and Simulation Model of Intelligent Transport Systems in Ports), Doctoral dissertation, Faculty of Transport and Traffic Sciences, Zagreb, 2004

[12] Bukljaš Skočibušić, M.: Model međuobalne plovidbe i povezivanje Republike Hrvatske s EU (Short Sea Shipping Model and Integration of Croatia with EU), Doctoral dissertation, Faculty of Transport and Traffic Sciences, Zagreb, 2007

[13] http://europa.eu.int/comm/transport/intermodality/ motorways_sea/index_en.htm 